\title{
Breaking middle income traps in a post Covid-19 world: an introduction to the Special Issue
}

Romper a armadilha da renda média no mundo pós-Covid-19: uma introdução ao Número Especial

\author{
Glenda Kruss (1) \\ Keun Lee (2) \\ KJJoseph ${ }^{(3)}$ \\ Eduardo da Motta e Albuquerque (4)
}

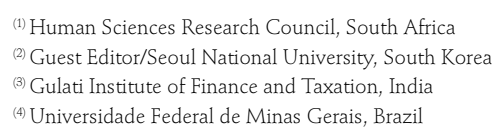

(1) Human Sciences Research Council, South Africa

(3) Gulati Institute of Finance and Taxation, India

(4) Universidade Federal de Minas Gerais, Brazil

\section{Introduction}

This Special Issue of Nova Economia presents papers from the workshop "Development, Lock-Ins, Traps and Catch Up: India, China, South Africa, South Korea and Latin America" that took place at Universidade Federal de Minas Gerais (UFMG), Belo Horizonte, Minas Gerais, between 8 and 10 July 2019.

This 2019 workshop was a continuation of another workshop - "Political Economy of The Middle Income Trap (MIT hereafter)", the $26^{\text {th }}$ SJE International Symposium - that took place at the Seoul National University, 3 July 2018.

The two workshops led to two special issues. The first appeared in the Seoul Journal of Economics, with five papers covering five countries: Thailand, Malaysia, Turkey, Mexico, and Brazil (Lee, 2019a). The second is the present Special Issue, with six papers covering four countries (South Africa, India, China, Brazil), one region (Latin America) and experiences of successful cases of catch up (especially South Korea).

This introduction draws on the insights gained from both workshops, as reflected in the two special issues, to suggest an integrated reading of the current state of the research field. Taken together, the eleven papers provide resources to evaluate different aspects of a wide range of countries that, in at least in one phase of their histories, faced an 'income' trap related to their levels of development.

The middle income trap was discussed at both workshops, which, however, also, discussed related issues. ${ }^{1}$ It was seen that, on the one hand, 
countries may face low-income traps and/or low-level equilibrium traps (Nelson, 1956). On the other hand, countries may overcome those traps, upgrading their position, in a transition from a low income to a middle income level, and eventually overcoming that middle income trap. According to the World Bank (2012, pp. 12), a country can be considered to be in the MIT if its per capita income remains in the $20 \%$ to $40 \%$ range of US per capita income for several decades. More generally, Celso Furtado (1992, pp. 37-59) mentions an "underdevelopment trap". Since sometimes the boundaries between low income and middle income are not very clear, one option is to discuss "traps" from a broader perspective.

Countries can be trapped in their economic trajectories by a variety of causes, as discussed in the eleven papers published in SJE and NE. Traps, more generally, may be understood as a sort of "lock in" that defines "stalled development trajectories", constraining a country to preserve its previous position. As the data and the historical evidence presented in the eleven papers show, such long term traps may be decomposed by reductions in the income gap vis-à-vis developed countries (a limited catch up period), followed by an increase in those income gaps (limited falling behind period).

The literature on traps, especially middle income traps, focuses on a process that has at least two dynamic components: the leading countries, which are sources of renewed technological dynamism that feed income growth at the center; and the countries at the periphery, always at least trying to absorb technological progress created at the center. This two-sided dynamic process opens possibilities of various scenarios, illustrated by two extreme cases. On the one hand, stagnation of the backward country that does not follow the growth of the leading country: a scenario of falling behind. On the other hand, intense growth of a peripheral country that enables it to catch up. Between those two extreme cases, there are various traps, sequences of ups alternated with downs, and, as the outcome, a trap: neither a catch up nor a falling behind.

Therefore, the questions might be asked: why are these phases of gapreducing not persistent? Why do these surges of limited catch up fizzle, and why is persistent catch up an exception? To the extent that the COVID-19 pandemic impacts on the GDP and growth trajectory of all countries, a further pertinent question relates to the enhanced or reduced prospect of escaping these traps in the post COVID period. 
The eleven papers present topics, evaluations, data and information on these traps from different points of view, and at different phases, sometimes focusing on specific problems.

There are nine countries, from four different continents: India, China, Malaysia, Thailand, and South Korea in Asia, South Africa in Africa, Turkey in Europe and Asia, Mexico and Brazil in America. Such broad geographical coverage may enhance our understanding of different dynamics behind the middle income trap.

\section{A look at the trajectories of nine countries}

A first step in the analysis is a systematization of data to compare the long term trajectories of our nine countries. Graph 1, using data from Maddison's database, illustrates what the countries have in common, and highlights the very special case of South Korea, the only one of these countries to escape the middle income trap.

Figure 1 Ratio of GDP per capita between selected countries (South Africa, India, Thailand, Malaysia, China, South Korea, Turkey, Mexico and Brazil) and the United States (1870-2008)

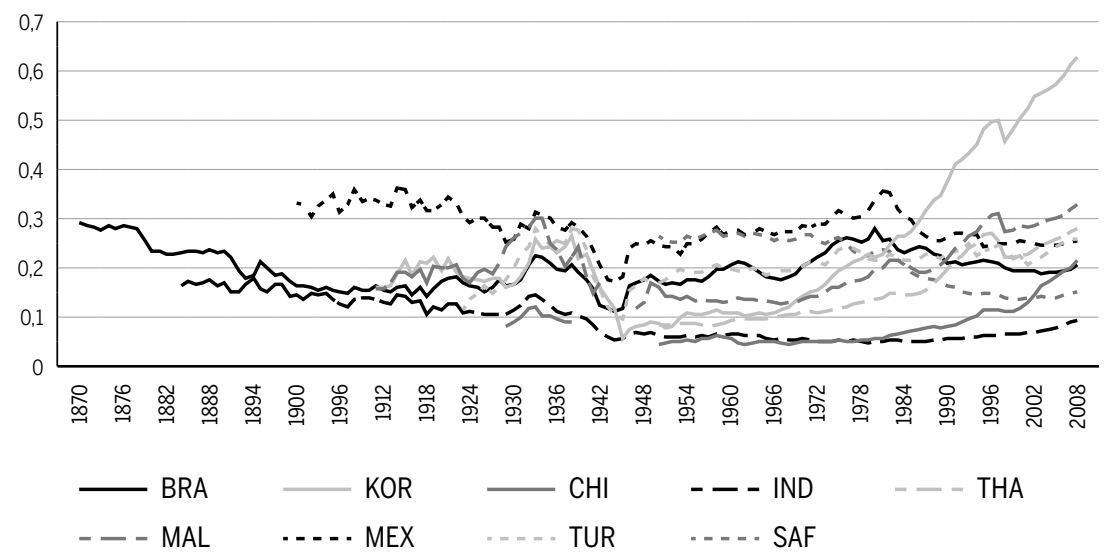

Source: Maddison (2010), authors' elaboration.

Note: GDP per capita in 1990 International Geary-Khamis dollars. 
Table 1 organizes the available data for selected years over a long period (1870, 1913, 1950, 1978, 1990 and 2008), including the averages, standard deviation and coefficients of variation for those years.

Table 1 Ratio of GDP per capita between selected countries (South Africa, India, Thailand, Malaysia, China, South Korea, Turkey, Mexico and Brazil) and the United States (Y), average, standard deviation of coefficient of variation $-1870,1913,1950,1990$ and 2008

\begin{tabular}{lrr|r|r|r|r}
\hline Country & $\mathbf{Y ~ ( 1 8 7 0 )}$ & $\mathbf{Y ~ ( 1 9 1 3 )}$ & $\mathbf{Y ~ ( 1 9 5 0 )}$ & $\mathbf{Y}(\mathbf{1 9 7 8 )}$ & $\mathbf{Y}(\mathbf{1 9 9 0 )}$ & $\mathbf{Y ( 2 0 0 8 )}$ \\
\hline BRA & 0,291647 & 0,152996 & 0,174842 & 0,254635 & 0,201656 & 0,206203 \\
\hline KOR & 0,247079 & 0,164014 & 0,089306 & 0,22119 & 0,457437 & 0,629098 \\
\hline CHI & 0,216801 & 0,104193 & 0,046858 & 0,053228 & 0,111483 & 0,215692 \\
\hline IND & 0,218081 & 0,126872 & 0,06474 & 0,052554 & 0,065946 & 0,095418 \\
\hline THA & 0,248693 & 0,158583 & 0,085453 & 0,131805 & 0,221441 & 0,280652 \\
\hline MAL & 0,271001 & 0,169812 & 0,16308 & 0,178008 & 0,274978 & 0,330113 \\
\hline MEX & 0,275722 & 0,326659 & 0,247352 & 0,304531 & 0,25153 & 0,255913 \\
\hline TUR & 0,337465 & 0,228836 & 0,169739 & 0,231564 & 0,242397 & 0,258723 \\
\hline SAF & 0,350919 & 0,302219 & 0,265124 & 0,227186 & 0,140685 & 0,15374 \\
\hline Average & 0,271001 & 0,164014 & 0,16308 & 0,22119 & 0,221441 & 0,255913 \\
\hline St Dev & 0,047465 & 0,077055 & 0,078626 & 0,088152 & 0,113476 & 0,151664 \\
\hline Coef Var & 0,175147 & 0,469806 & 0,48213 & 0,398538 & 0,512445 & 0,592639 \\
\hline Sour
\end{tabular}

Source: Maddison (2010), authors' elaboration.

Notes: GDP per capita in 1990 International Geary-Khamis dollars.

Analysis using Maddison's data shows that the mean gap in 1870 was very similar to that in 2008 - but that heterogeneity has grown. Table 1 shows that in 1870 the nine countries reflect a mean gap around 0.273 , very similar to the position in 2008 , with a mean gap of 0.256 , but the heterogeneity of this group grew - from a coefficient of variation of 0.18 in 1870 , to 0.59 in 2008.

From 1870 to 1913 the group as a whole had a falling behind phase, reaching a mean gap of 0.164 . During the inter-war years, this level persisted almost unchanged, with the resulting similar relative position until 1950 (mean 0.163). That year is a benchmark, because there was the aftermath of Korea's liberation from colonization (1945), Indian independence (1947), the foundation of the People's Republic of China (1949), and the eve of independence in Malaysia (1957). Table 1 reflects a gap-reducing phase between 1950 and 2008, for all countries except South Africa. There 
were diverse processes in each country, but there was one dominant outcome - a limited catching up phase.

After the late 1960s the heterogeneity grew, with at least two trajectories becoming evident, as Graph 1 shows. First, a very similar trajectory is evident in South Korea, Malaysia, Thailand and China: although at different levels, all four countries reduced their gap vis-à-vis the USA until 1997, then all had a shock in 1997, and, after that, went through a recuperation process that led to a smaller gap than the one existing prior to 1997. Second, a very similar trajectory is found between Mexico and Brazil, with a peak by the late 1970s, and later, a falling behind process without subsequent recuperation.

For the group as a whole, the case of South Korea is an exception, in that the country rose from the middle income level - in 1991 the gap was 0.41 , in 2008 it was 0.62 .

Graph 2 shows data from the World Bank for 1990 and 2019, and the current position of these countries.

Figure 2 Ratio of GDP per capita between selected countries (South Africa, India, Thailand, Malaysia, China, South Korea, Turkey, Mexico and Brazil) and the United States (Y) -1990 a 2019

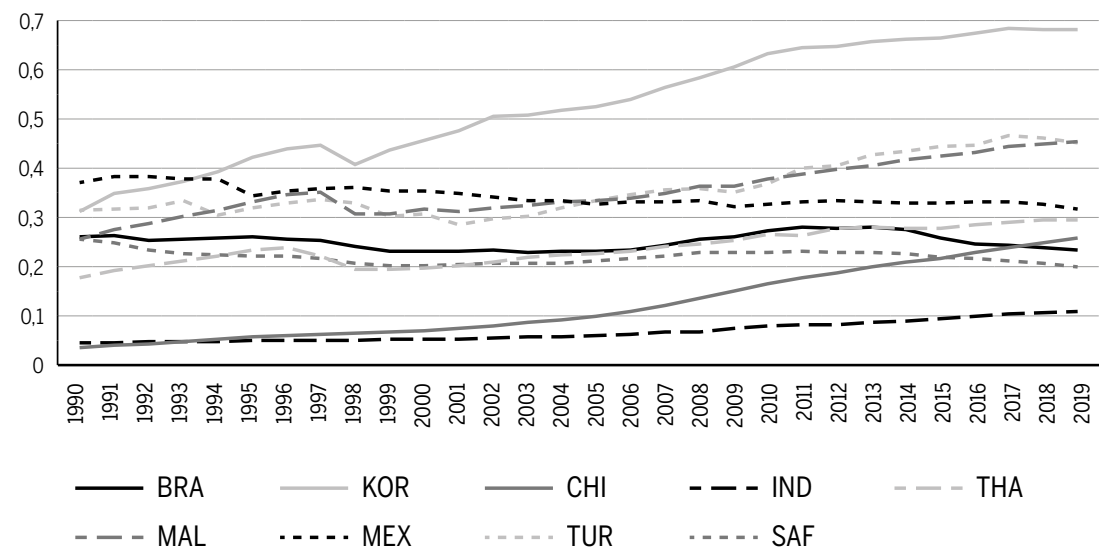

Source: World Bank (2020), authors' elaboration.

Note: GDP per capita in 2017 constant international \$.

By aggregating data for the following eleven years, including the years related to the 2007-2008 crisis and its subsequent dynamics (Tooze, 2018), 
Graph 2 provides additional information. In this shorter and more recent period, there is one clear differentiation. On the one hand, there are countries like South Korea, China, Thailand, Malaysia and India that clearly reduced their gap with the USA after 1990. On the other hand, there are countries like South Africa, Brazil and Mexico that widened the gap vis-àvis the USA since 1990.

Table 2 helps to interpret this data, showing the comparison between the gaps in 1990 and 2019 and the calculation of their change over this period.

Table 2 Ratio of GDP per capita between selected countries (South Africa, India, Thailand, Malaysia, China, South Korea, Turkey, Mexico and Brazil) and the United States ( $Y$ ), average, standard deviation, coefficient of variation and change between 1990 and 2019

\begin{tabular}{lrrrr}
\hline Country & $\mathbf{Y ~ ( 1 9 9 0 )}$ & $\mathbf{Y ( 2 0 1 9 )}$ & Change 2019/1990 \\
\hline SAF & 0,254229 & 0,199623 & 0,785208 \\
\hline TUR & 0,314129 & 0,450484 & 1,434072 \\
\hline IND & 0,044686 & 0,108022 & 2,417367 \\
\hline MAL & 0,254515 & 0,453414 & 1,78148 \\
\hline THA & 0,175531 & 0,295282 & 1,682222 \\
\hline CHI & 0,035153 & 0,257756 & 7,332487 \\
\hline KOR & 0,312832 & 0,682285 & 2,180994 \\
\hline MEX & 0,369659 & 0,315807 & 0,854321 \\
\hline BRA & 0,259692 & 0,234325 & 0,902319 \\
\hline Average & 0,254515 & 0,295282 & \\
\hline St Dev & 0,117534 & 0,171691 & \\
\hline Coef Var & 0,461795 & 0,581448 & \\
\hline
\end{tabular}

Source: WORLD BANK (2020a), authors' elaboration.

Note: GDP per capita in 2017 constant international \$.

On the one hand, there are countries, although at different levels, that reduced their gap with the USA by more than double - China, India and Korea. On the other hand, there are countries that widened the gap vis-àvis the USA: Brazil, Mexico and South Africa. Between those two groups there are countries that reduced the gap, but by less than double: Malaysia, Thailand and Turkey.

The analyses thus show that the outcome of economic processes over time is a more heterogeneous group of countries: in 2019 the gaps range 
from 0.10 to 0.70 (Graph 1, Table 1), while in 1870 the range was narrow, between 0.21 and 0.35 (Graph 2, Table 2).

Between 1870 and 2019, the political arrangements and economic structures of each country changed significantly - changes necessary to preserve almost the same mean gap. All these economies are no longer predominantly agrarian, with uneven but significant levels of industrialization, and widely differing economic structures.

Amsden (2001, p. 1) defines "the rest" as a set of non-developed countries - "a handful of countries outside the North Atlantic" - that had in common a "manufacturing experience" before the Second World War, and that after 1950, had a trajectory of per capita income growth and industrial diversification. Amsden's "the rest" includes all of the countries discussed in this Special Issue except South Africa. ${ }^{2}$ However, South Africa would fit in her description of "the rest", as it had a very peculiar industrialization trajectory, evolving from a "minerals-energy complex" towards industrialization (Fine et al., 1996), from 1948 until the early 1990s, which depended upon the "apartheid government's policy interventions in the face of global sanctions, to the benefit of a racially defined elite" (Kruss, 2020, p. 1125). As our Graphs 1 and 2 show, South Africa's trajectory fits well with patterns of our group of countries, and is not an exception.

A reference to Amsden's book is useful because it helps us to put our group of countries in a broader perspective, and to identify the specific contributions of the SJE and NE papers.

First, Amsden (2001, p. 13) also used Maddison data to organize her arguments, going back to 1850 . Her book is organized in three parts that capture the different movements reflected in our Graph 1 and Table 1. Amsden's first part describes a predominantly falling behind period described as "sinking behind, 1850 - circa 1950"; the second part describes a predominantly "catching up" period, described as "sneaking ahead, circa 1950-..."; and the third part describes structural changes in a new phase, described as - "squaring off, circa 1980 - ...". This last phase contains two crises - 1982 in Latin America, 1997 in East Asia (Amsden, 2001, p. 251) that can be identified in Graph 1. These crises, and the responses to them,

2 Amsden's "the rest" includes "China, India, Indonesia, South Korea, Malaysia, Taiwan, and Thailand, in Asia: Argentina, Brazil, Chile, and Mexico in Latin America, and Turkey in the Middle East" (2001, p. 1). Amsden divides the world in three groups - the developed nations, and the "backward nations" divided between "the rest" and "the remainder" - backward countries without the industrial diversification achieved by "the rest". 
may be one of the sources of the differentiation between Latin American and East Asian countries. As Table 1 shows, the gaps in Brazil and Mexico widened between 1978 and 1990, while all countries in Asia diminished the gaps in that period. Table 1 also shows that by 2008, the Asian countries had recovered and overtaken their 1990 levels, while Brazil and Mexico had not even returned to their 1978 levels.

Second, Amsden describes the manufacturing experiences that the countries in "the rest" had before the Second World War, an important argument in her definition of this specific group of countries. These experiences could perhaps be further investigated to understand the historical roots of middle income traps.

Third, Amsden organizes information related to the policies that the countries had in common between 1950 and 1980, policies that may be related to the economic growth reflected in Graph 1 and Table 1, which she summarizes as a phase of "sneaking ahead". Some of those policies are presented and analyzed in the papers published in our two special issues - investments in education (Wong, 2019, p. 17), import substitution phases (Intarakumnerd, 2019, p. 109), industrial policies (Garcia et al., 2020), STI policies (Joseph et al., 2020; Wong et al., 2019, p. 13) and broad Economic Plans, as in Turkey and South Korea, between 1962 and 2014 (Yasar, 2019, p. 70).

Therefore, based on the work of Amsden (2001) and of Fine and Rustomjee (1996), we can discern a broad framework that shows how our nine countries had a "manufacturing experience" before 1945, and an industrialization trajectory after 1950. They were not homogenous, but they were no longer economies based only on agricultural and/or mineral resources sectors. Their levels and diversification of industrialization differed, but all of them had made important progress towards industrialization, especially between 1950 and 1980 .

\section{How do the papers in the special issues help to un- derstand the different trajectories?}

Graphs 1 and 2 and Tables 1 and 2, and our dialogue with Amsden (2001) provide a framework to better define the different trajectories evident among our nine countries. 
We identify three different trajectories, with some sub-groups within them: first, the five Asian countries, that had in common a reduction of their gaps vis-à-vis the USA between 1990 and 2019; second, Latin American countries and South Africa, that had increased their gaps between 1990 and 2019; and third, Turkey, because it was in the second position of the countries that had not completed their catch up in 1870 and is still in second position in 2019.

Table 3 Papers, authors, definition of stage, trajectory and main challenges pre-Covid-19

\begin{tabular}{|c|c|c|c|c|}
\hline $\begin{array}{l}\text { Country/ } \\
\text { Region }\end{array}$ & Paper(s) & Stage & Trajectory & \begin{tabular}{|l|} 
Pre-Covid-19 \\
Main Challenge
\end{tabular} \\
\hline South Africa & $\begin{array}{l}\text { Kruss } \\
(2020)\end{array}$ & Middle income & $\begin{array}{l}\text { staled } \\
\text { development }\end{array}$ & $\begin{array}{l}\text { Formation of a } \\
\text { "upgrading coalition" }\end{array}$ \\
\hline Malaysia & $\begin{array}{l}\text { Wong et al. } \\
(2019)\end{array}$ & Middle income & $\begin{array}{l}\text { Growth, in the eve } \\
\text { of overcoming the } \\
\text { MIT }\end{array}$ & $\begin{array}{l}\text { Improvement in educa- } \\
\text { tion and institutions, } \\
\text { vertical policy measures }\end{array}$ \\
\hline Thailand & $\begin{array}{l}\text { Intarakumnerd } \\
(2019)\end{array}$ & Middle income & $\begin{array}{l}\text { Growth with low } \\
\text { technological } \\
\text { learning }\end{array}$ & $\begin{array}{l}\text { Breaking with seven } \\
\text { detrimental habits in } \\
\text { innovation policies }\end{array}$ \\
\hline India & $\begin{array}{l}\text { Joseph et al. } \\
(2020)\end{array}$ & $\begin{array}{l}\text { Transition from low } \\
\text { income to middle } \\
\text { income }\end{array}$ & $\begin{array}{l}\text { Growth, consolida- } \\
\text { tion in the middle } \\
\text { income level }\end{array}$ & $\begin{array}{l}\text { Deindustrialization and } \\
\text { R\&D decline }\end{array}$ \\
\hline China & $\begin{array}{l}\text { Cerqueira et al. } \\
(2020) \text {, } \\
\text { Lee } \\
(2021)\end{array}$ & Middle income & $\begin{array}{l}\text { Resilient catch up } \\
\text { trajetory, com- } \\
\text { pressed catch up }\end{array}$ & $\begin{array}{l}\text { Preserve the catch } \\
\text { up trajectory and find } \\
\text { a new geopolitical } \\
\text { accomodation }\end{array}$ \\
\hline South Korea & $\begin{array}{l}\text { Feitosa } \\
(2020)\end{array}$ & High income & $\begin{array}{l}\text { Succesfull catch } \\
\text { up completed }\end{array}$ & $\begin{array}{l}\text { Post-catch up } \\
\text { consolidation policies }\end{array}$ \\
\hline Turkey & $\begin{array}{l}\text { Yasar } \\
(2019)\end{array}$ & Middle income & $\begin{array}{l}\text { Middle income } \\
\text { trap }\end{array}$ & $\begin{array}{l}\text { Reform in education } \\
\text { system, } R \& D \\
\text { investments }\end{array}$ \\
\hline $\begin{array}{l}\text { Latin } \\
\text { America }\end{array}$ & $\begin{array}{l}\text { Cimini et al. } \\
(2020)\end{array}$ & $\begin{array}{l}\text { Low and middle } \\
\text { income }\end{array}$ & "random walk" & $\begin{array}{l}\text { Overcome the passive } \\
\text { insertion in the global } \\
\text { economy }\end{array}$ \\
\hline Mexico & $\begin{array}{l}\text { Durán } \\
\text { (2019) }\end{array}$ & Middle income & $\begin{array}{l}\text { GVC-led } \\
\text { development }\end{array}$ & $\begin{array}{l}\text { Promotion of domestic } \\
\text { innovation capabilities }\end{array}$ \\
\hline Brazil & $\begin{array}{l}\text { Garcia et al. } \\
(2020)\end{array}$ & Middle income & $\begin{array}{l}\text { Failure to change } \\
\text { previous industrial } \\
\text { policies rules and } \\
\text { conventions }\end{array}$ & $\begin{array}{l}\text { Design of new industrial } \\
\text { and technological } \\
\text { policies }\end{array}$ \\
\hline
\end{tabular}

Source: papers the Special Issues of SJE (2019), NE (2020) and Lee (2021), authors' elaboration. 
A closer investigation of the three main trajectories using the papers in our two special issues may help to illuminate specific traits of the trajectories and disaggregate them further. Table 3 presents the list of papers, their subject and main points.

The Asian countries had in common a reduction in the gaps between 1990 and 2019, but this reduction took different forms.

South Korea is an example of the possibility of overcoming underdevelopment (Furtado, 1992) and escaping the MIT (Lee, 2013).

An overall assessment of South Korea's catch up process is presented by Feitosa (2020) in his review of Keun Lee's systematization and investigation, a useful and necessary broad view of its foundations, providing potential lessons for underdeveloped countries. ${ }^{3}$ Feitosa articulates Lee's reflections on recent South Korea catch up with previous elaboration and theory of catch up - Gerschenkron, Abramovitz, Perez and Soete, Amsden and Wade. The reader will have a broad picture of those authors and will have the opportunity to understand the context of the South Korea case. Feitosa organizes his paper around the main points of Keun Lee's elaboration - "the Korean transition pathway", that involves "building innovation capabilities", "promotion of business groups", skipping stages and "path creation". As Feitosa summarizes, "These efforts have enabled the country to create a different path of development and not merely follow the path of technological development of the advanced countries...". The main lessons for latecomers are a suggestive sequence composed of three steps: "late entry - detours - leapfrogging" (p. 1161). The most important detours are "establishment of an intellectual property regime that facilitates imitative innovation", "specialization in short-cycle technology-based sectors and products (i.e., information technology) in the first stages of development", "joining the global value chains (GVC) by the creation of domestic value-added and reducing the dependence on foreign value-added" (pp. 1161-1162). China might be an exceptional case, given the size of the country, an example of a persistent catch up trajectory, inaugurated in 1949 (Naughton, 2007). That exceptionality includes its initial point in 1950, that was the lowest point in its gap vis-à-vis the USA (Graph 1 and Table 1), of this post-Second World War process. China's path also shows a resilience and a capacity to keep the catch up trajectory after changes in both political and economic

3 Lee's The art of economic catch up book launch can be seen in Lee (2019b). 
organization - the transition from the "Maoist model" to a new variety of capitalism (Szelényi, 2008) - and in stages of development (Lee, 2021).

The case of Chinese catch up was discussed by Keun Lee in the Workshop in Belo Horizonte and the contents are deeply related to the introduction of his forthcoming book - China's Technological Leapfrogging and Economic Catch-up: A Schumpeterian Perspective. ${ }^{4}$ Keun Lee presents the peculiarities of the Chinese process, stressing "unique features" that differ from South Korea's and Taiwan's catch up (see Feitosa, 2020, for the main characteristics of those processes). Describing the current Chinese process as a "compressed catch up", for Keun Lee (2021), those peculiarities are: "first, parallel learning from FDI firms, followed by active promotion of indigenous firms; second, forward engineering (the role of university spinoff firms) in contrast to reverse engineering adopted in Korea and Taiwan; third, acquisition of foreign technology and brands through international M\&A". Furthermore, size matters in the Chinese case, which imparts a bargaining power important for its strategies of technology transfer and international M\&A (Lee, 2021). In common with South Korea and Taiwan, the Chinese process also "identifies firms and the state developmental agency as the two primary vehicles for latecomer development". China avoided the "liberalization trap", "where premature financial liberalization leads to macroeconomic instability, by following the East Asian sequencing rather than the Washington Consensus" (Lee, 2021). Currently, as the title of his new book indicates, China is facing a double challenge, one related to policies to overcome the MIT, and the other to geopolitical conditions driven by its continuous growth that may lead it to a position of the wealthiest nation in the world - this would be the Thucydides trap (Lee, 2021). China as the largest GDP in the world is a ranking that took place before the first shock with the British Industrial Revolution in the XIX ${ }^{\text {th }}$ Century - this shock and its consequences, roots of long lasting traps faced by China in the late XIX ${ }^{\text {th }}$ and throughout the $\mathrm{XX}^{\text {th }}$ Century, are discussed by Cerqueira et al. (2021).

Malaysia and Thailand seem to follow a very similar trajectory, especially after the 1990s. Graph 1 shows the similar movements before the 1997 crisis, the fall after that crisis, and how, after 1998, both countries resumed the reduction of the gap with USA.

4 Lee's presentation on China in the Workshop in Belo Horizonte can be seen in Lee (2019c). 
Malaysia has a peculiar position, as the paper by Wong et al. (2019) evaluates whether or not it had already reached a condition to break the MIT, whereas Lebdioui et al. (2020) claim that Malaysia is moving beyond the MIT, as its per capita GDP has surpassed the $40 \%$ level of that of the US, reaching close to $50 \%$ in the late 2010s (see also Graph 2). According to Wong et al. (2019, p. 2), "Malaysia has shown above average performance against population growth, thereby indicating that this country may or may not have the potential to join the rest of NIEs" (newly industrialized economies). The "promise in breaking MIT" is a consequence of transformation of "many informal economic activities into formal ones", an "economic growth of approximately $5 \%$ for decades and low unemployment", and "the influx of foreign direct investments (FDI), particularly from China" (p. 2). Wong et al. (2019) evaluate the potential for "breaking MIT" by investigating "income and FDI" (pp. 6-10), "economic structure" (pp. 10-13) - that was transformed "from an agricultural and mining economy to manufacturing" between 1980 and 2015 (p. 11) -, "upgrading" (p. 13-15), "social capital" (p. 16-17) and "education" (p. 17-19).

Actually, according to a most recent paper by Lebdioui et al. (2020), Malaysia and Chile are showing some signs of growth beyond the middle income trap, owing to their success not in manufacturing but in several resource-based sectors, such as petroleum, rubber and palm oil sectors in Malaysia, and salmon, fruits, wine and forestry in Chile. These sectors are not just domestic market-oriented but export-oriented, and further, they are not exporting crude resources but processed or high-value-added goods. These cases imply the possibility of resource sectors serving as the engine of export-oriented growth in resource-rich countries. In the meantime, key challenges for Malaysia are the lack of "good governance among policymakers with a focus on building export capabilities", "[t]he lack of technology transfer... because Malaysian firms have insufficient capability to develop competitive products", and the "lack of effective measures in improving education" (Wong et al. 2019, p. 19).

Thailand was a "high-performing Asian economy", which from the 1960s to the 1990s had a growth rate that "exceeded 7\%" (Intarakumnerd, 2019, p. 109). This trajectory can be divided in three phases: "import substitution (late 1950s-1970s), export promotion (1980s-mid 1990s), and liberalization (late 1990s onward)" (p. 109). According to Intarakumnerd (2019, p. 110), in comparison with other Southeast Asian economies, the 
Thai economy is "rather unique" "because no class of indigenous big business entrepreneurs exists in the country". This may be one reason for the first of the factors behind Thailand's MIT: the "low level of technological and innovative capabilities and passive learning of Thai firms" (p. 113). After the crisis of 1997 "few interesting positive changes" took place (Intarakumnerd, 2019, p. 112): large Thai conglomerates increased their $R \& D$ activities, small companies increased collaboration with universities, subcontracting suppliers in auto and electronics sectors increased their efforts in design and efficiency, and new start-up firms emerged. Graphs 1 and 2 show how Thailand was affected by the 1997 crisis, but also how it recovered later. A second reason may be "the highly ineffective science, technology and innovation policy habits": excessive focus on R\&D promotion, firms as "users" of university knowledge, indigenous innovative capabilities not being a major objective, selective policies, "TNCs should be left alone", constraints in government grants to firms, and excessive attention to post-graduate level (Intarakumnerd, 2019, pp. 116-127). Changes to break the MIT would involve "many additional innovative firms" and "the enhancement of firms' technological and innovative capabilities should be at the center of STI policies" (p. 129).

In its struggle to reach a middle income position, India too has a peculiar position in the Asian trajectory of gap-reduction. Joseph et al. (2020) summarize the early emphasis on innovation in India's development policies since at least 1958, with the Science Policy Resolution, and by the Patent Act of 1970 (p. 1205). ${ }^{5}$ The importance of innovation for India is reflected in the size and scope of its scientific and technological infrastructure built since Independence. Joseph et al. (2020) focus on policy changes of policy in the early 1980s, "a shift in policy pendulum from planning to market, and from import substitution to export orientation and globalization" (p. 1200). Their article evaluates the impacts of this policy change on deindustrialization and related structural changes. The gist of their analysis is whether or not those new policies, with a strong bias towards globalization, have been successful in achieving higher levels of innovation for the Indian economy as a whole. Data on the contribution of different sectors of the economy to employment and GDP (see Figures 1 and 2, p. 1209 and p. 1210), show that in 2016 the service sector was leading one in both. The 
share of manufacturing in GDP declined, leading to an investigation of the quality of employment, with data showing the importance of informal and unorganized sectors in manufacturing (see Figure 4, p. 1213). Data also show that in the most recent phase - 1996-2017 - both wage growth and labor productivity growth diminished vis-à-vis the earlier phase - 19801995 (see Table 1, p. 1215). Those changes are correlated to changes in $R \& D$ intensity that declined after 2007, resuming the levels of 1996 (see Figure 7, p. 1217). Joseph et al. (2020) conclude that the strategies shaped by globalization led to a "failure to build a vibrant learning, innovation and competence building system as has happened in case of the successful catch up episodes" (p. 1221).

The second trajectory was followed by South Africa, Mexico and Brazil, that have in common a regression in their positions vis-à-vis the USA between 1990 and 2019.

Kruss (2020) highlights the hope brought forward by South Africa ending apartheid and transiting to democracy, that included "great expectations for economic catch up" (p. 1116). ${ }^{6}$ Political transformation is very important for later economic policies of development, as the changes around 1950 were for advances in industrialization and catch up - even limited catch up between 1950 and 1978, as shown in Graph 1 and Table 1. However, in the South African case, that essential political transformation did not lead to a straight developmental path. Kruss shows the historical roots of "a long history of relative underperformance reflecting a stalled trajectory" (p. 1118), that runs the risk of falling behind (p. 1120). Kruss reviews the literature on the middle income trap and on its relationship with inequality, possibly a strong blocking factor for development, a pattern that South Africa shares with Latin American countries. Table 4, below shows the Gini Indexes for our nine countries, highlighting how Brazil, Mexico and South Africa are more unequal.' Inequality, a tragic inheritance from the apartheid system, has deep roots in South Africa history and, as in Latin America (see Cimini et al., 2020), it is very difficult to be overcome. Therefore, Kruss highlights the political dimension as a key prerequisite for catch up, and discusses how to build "upgrading coalitions" to trighas led to an outflow of skilled talent". Table 3 shows that Malaysia has a Gini Index of 0.41 , lower than South Africa, Brazil and Mexico, but higher than the other Asian countries. 
ger development. Such "upgrading coalitions" may include neqa2w3esxdc vy7 nlp0/w paths, as Kruss in a dialogue with Lee's elaboration, suggests "a new kind of detour: building an upgrading coalition around livelihoods in the informal sector".

Table 4 Gini Indexes, selected countries (South Africa, India, Thailand, Malaysia, China, South Korea, Turkey, Mexico and Brazil), for the last available year

\begin{tabular}{lrr}
\hline Country & Gini Index & Year \\
\hline SAF & 63.0 & 2014 \\
\hline TUR & 41.9 & 2018 \\
\hline IND & 35.9 & 2011 \\
\hline MAL & 41.0 & 2015 \\
\hline THA & 36.4 & 2018 \\
\hline CHI & 38.5 & 2016 \\
\hline KOR & 31.6 & 2012 \\
\hline MEX & 45.4 & 2018 \\
\hline BRA & 53.9 & 2018 \\
\hline
\end{tabular}

Source: World Bank (2020b), authors' elaboration.

Latin America may have a common background that goes back to the colonial times, as discussed by Cimini et al. (2020), who focus on a region rather than a single country. ${ }^{8}$ This approach helps to shed a light on what Brazil and Mexico have in common, by searching for historical roots related to the processes of Independence during the early XIX ${ }^{\text {th }}$ Century - a process that led to political fragmentation, in contrast to the unification process of the English colonies in the late XVIII th Century. These processes may be at the root of the later lack of market integration that was a source for potential economies of scale and scope that Chandler (1977) stresses as key for the emergence of the modern industrial enterprise in the USA. Cimini et al. (2020) also evaluate the common roots in the region for the economic dependence upon natural resources that could have later become one of the components of the region's generalized capture by the MIT. Cimini et al. (2020) present another broad contribution to the literature, as they explore an empirical tool (Hurst exponent) that differentiates the economic dynamic at the center of capitalist systems - economies with 
self-organization - and at the periphery - economies still with "random walk" features, therefore not self-organized. Cimini et al. (2020) use data from Maddison to test their hypothesis, finding that Latin American countries in their sample and India have that "random walk" nature - their internal dynamics are not stable, they do not have forces that preserve a dynamic supported by previous growth, and they are not self-organized. This differentiation might suggest that the dynamics in Latin America and India may be more defined by external forces and by impacts coming from abroad than by domestic forces.

Durán (2019) presents Mexican specificities, starting with a description of long term growth of manufacturing: "[d]uring the last 50 years, manufacturing value added in Mexico has multiplied by almost four times" (p. 84). The paper argues that "Mexico, in the aftermath of the debt crisis, developed a large export platform but with low linkages with the rest of the economy" (p. 84). After "getting out of the natural resources trap", Mexico choose to "promote GVCs" (pp. 85-86). This choice involved a "new manufacturing mix with low investment coefficients" (p. 87). The role of foreign investment is evaluated. For example, Table 2 (Durán, 2019, p. 88) demonstrates how in the "transportation equipment manufacturing" FDI accounted for 24.7 percent of capital formation in manufacturing. With a process of manufacturing restructuring "led by different forces", Durán (p. 90) identifies an "uneven process of promotion in the regions" that resulted in three waves of investment, each concentrated in one region of Mexico. The outcome in terms of industrial agglomeration is that although investments led to the insertion of Mexico in various GVCs - autos, electronics, pharmaceuticals, and medical devices - an evaluation of their role in increasing the "density of Mexican manufacturing" over the "last 30 years" is mixed. These policies led to "greater integration into GVCs, but - by itself - does not lead to an upgrade in production" (p. 102), more FDI "per se does not generate significant linkages with the rest of the economy" (p. 103) and the policies do not develop "domestic innovation capabilities" (p. 103). In short, GVCs do not overcome the middle income trap.

Duran's conclusion is consistent with Lee et al. (2018), who argue that for a country to escape MIT requires going through a specific stage in which it reduces reliance on GVCs, by increasing the share of domestic value-added in its gross exports. Such was the case in the experience of South Korea during the mid-1980s to the late 1990s, and more recently, 
in China in the 2000s. This view suggests a nonlinear, or the "In-Out-In Again" pattern of GVC participation. At the initial stage of growth by a latecomer, increased participation in GVCs is necessary to acquire foreign knowledge and production skills, but for the functional upgrade at the middle-income stage, effort must shift to seek separation and independence from existing foreign-dominated GVCs, in order to increase domestic value-added. Finally, after establishing their local value chains, latecomer firms and economies may have to seek reintegration into the GVC. The transient separation from GVCs at the middle-income stages to increase domestic value-added and to develop technological capabilities is critical.

Garcia et al. (2020) introduce their paper with an assessment of the formation of the Brazilian NSI and its relationship with catch up, focusing on industrial policies and institutions. ${ }^{9}$ Albuquerque (2019) may help to locate these policies historically, as a long-term trajectory of Brazilian economy under the "underdevelopment trap" - the MIT since 1870 is reviewed. Brazil had effective industrial policies in the late 1950s and in the 1970s, as Suzigan and Villella (1997) show. These previous partially successful industrial policies led to industrialization and even to building some capabilities in sectors such as capital goods. Those experiences explain why Garcia et al. (2020) start their analysis with the "revival of industrial policy in Brazil" after 2003. That revival involved a sequence of three different programs PITCE, between 2003-2007; PDP, between 2008-2010; and PBM, between 2011-2014. As shown in Graph 2 and Table 2 above, those policies were not effective in pushing ahead even a limited catch up period. Garcial et al. (2020) evaluate why, discussing how difficult it is to change "conventions", as they comment in their final remarks. Given the weight of the mining sector in Brazil, they present an evaluation of the mining sector and its technological strengths and weaknesses, an important point to understand the role of traps in natural resources that might be at the roots of MIT, as is the case in South Africa (Kruss, 2020).

And finally, there is Turkey that has a trajectory that does not fit either the Asian pattern or the Latin American pattern. Both in 1870 and 1913, Maddison's data placed Turkey in the second position among our nine countries (as part of the Ottoman Empire), and in 2019 the World Bank ranks it third. This distinctive trajectory is likely related to the fact that 
Turkey has a long term economic dynamic more directly influenced by forces from Europe.

The Ottoman Empire, according to Amsden (2001) had manufacturing experience in textiles and silk production, and after the creation of the Republic in Turkey in 1923, an initial experiment with steel production took place in 1939 - albeit a disappointment. Yasar (2019) highlights changes in economic development after the Second World War, and describes the Development Plans in Turkey since 1963 - the establishment of the State Planning Office took place after 1960 and is related to "the start of Turkish postwar economic expansion" (Amsden, 2001, p. 20). Between 1963 and 2018 there were ten Development Plans, although the comparison between "planned growth" and "actual growth" shows that planning may have been effective only until the Third Plan (1973-1977). Even in those three first economic plans, Turkey's economic growth was always below the planned value, in contrast to South Korea. The Development Plans changed the structure of Turkey's economy, so that vehicles and electrical machinery became, respectively, the first and the fifth "trade chapters" in 2016. The main failure in Turkish policies is the lack of "knowledge-based education for the population" (p. 78). One important problem was that "Turkey opened its economy before it prepared the appropriate situation for foreign trade in 1980" (p. 79). A major reform is needed in the education system, and incentives for $\mathrm{R} \& \mathrm{D}$ expansion should be included in new policies (Yasar, 2019 p. 79).

Although the eleven papers have different focuses, cover different time frames, and propose different sorts of policy solutions, together they help the reader to build a broader picture of the problems related to traps and lock-ins. For example, the exhaustion of industrial policies, that had been functional earlier, is a subject of a discussion in Brazil (Garcia et al., 2020), but this type of problem may be applied to other countries that had previous successful industrial policies. Another example is the impact of insertion in GVCs, discussed in detail in the Mexican case (Durán, 2019), but certainly useful for lessons in other countries. A final example relates to the very basic sequence of preparation of the economy, and opening up of the economy, as discussed in the case of Turkey (Yasar, 2019, p. 79), which opened before being sufficiently prepared.

Therefore, a reading of the eleven papers may help to understand how very specific topics may be important in various countries under the same 
curse: the middle income trap. An outcome of this collection of papers may be a broader view of those traps, as a variegated process with sometimes similar trajectories and end results.

\section{Covid as a new challenge for an old trap}

The initial responses to the pandemic - a politically induced recession to avoid a public health catastrophe (BIS, 2020, p. ix) - defined the subsequent economic processes. The data presented in Table 5 suggest that the outcomes of the policies implemented in our nine countries may be reflected in the estimates of GDP growth in 2020 (World Bank, 2021). The USA reflected a -3.6 per cent change in 2020 (World Bank, 2021, p. 4). Taking this recession as a benchmark, our nine countries can be divided in two groups. There is a group of countries that had GDP growth higher than the USA, or a negative growth smaller than the USA: China, Turkey (World Bank, 2021, p. 4) and South Korea (IMF, 2021). The other group, seven countries, experienced larger recessions than the USA.

Table 5 GDP growth (estimate), selected countries (USA, South Africa, India, Thailand, Malaysia, China, South Korea, Turkey, Mexico and Brazil) - 2020

\begin{tabular}{lrr}
\hline Country & GDP growth (estimate) 2020 \\
\hline USA & -3.6 \\
\hline SAF & -7.8 \\
\hline TUR & 0.5 \\
\hline IND & -9.6 \\
\hline MAL & -5.8 \\
\hline THA & -6.5 \\
\hline CHI & 2.0 \\
\hline KOR & -1.9 \\
\hline MEX & -9.0 \\
\hline BRA & -4.5 \\
\hline
\end{tabular}

Source: World Bank (2021) and IMF (2021) for South Korea, authors' elaboration.

This might be the first implication of the pandemic for breaking out of the middle income trap: with the exception of China and Turkey, since South Korea had already overcome this trap, countries are increasing their gaps. 
Data in Table 5 are GDP and not GDP per capita used to calculate the income gap vis-à-vis the USA in Table 1 and 2, but the trend in GDP at least provides the direction of those changes. ${ }^{10}$

Probably, the experiences of China and South Korea with previous epidemics might have contributed to their response to Covid-19. Korea had suffered from several virus/disease cases in recent years, such as the SARS (severe acute respiratory syndrome) virus in 2002 and the MERS (Middle East Respiratory Syndrome) virus in 2012, and thus built some systemic capacity to handle similar situations. For both China and South Korea, previous advances in digitalization of their economies might have contributed to a switch to remote modes of business, schooling and all other social activities.

The formation of the scientific institutions of innovation systems, especially related to health-related research institutions, may have some impact in the handling of this pandemic. A very simple and preliminary analysis of the leading scientific disciplines per country, to locate the significance of health-related disciplines, may help. A search of the WebOfScience for the leading 20 scientific disciplines in each country (data for 2017-2021) shows that in eight countries, there are at least 4 health-related disciplines in leading positions (South Africa 7, Mexico 4, Turkey 8, Korea 6, India 4, China 4, Thailand 8, Brazil 9). In Malaysia, there was only one in the 20 leading disciplines, but in the next six, there are 3 health-related disciplines. ${ }^{11}$

This long term institutional building in health-related research may help to block further deterioration due to the COVID pandemic. In South Africa, where health may be seen as an island of excellence within its innovation system, scientists were very quickly able to contribute to the global effort to find a cure for the virus, by sequencing the genome of a local sample of severe acute respiratory syndrome coronavirus 2 (SARSCOV-2). ${ }^{12}$

In the case of China, previous investments and a push triggered by the pandemic, may have contributed to a "turning point", as a recent article in Science puts forward (Normile, 2021).

10 As soon as the data on GDP per capita are available, Table 4 can be updated.

11 Those investments may be related to various initiatives for Covid-19 vaccines to have participants from our nine countries: firms and institutions from those countries are listed in those initiatives, according to WHO (2021) and Zimmer et al. (2021).

12 IOL (2020). 
In the case of India, previous investments in manufacturing established a domestic pharmaceutical industry (Joseph and Abrol, 2009, p. 103) that now is able to be the second global manufacturer of vaccines (Deutsche Welle, 2020), after the USA and before China.

If, as Table 5 shows, the initial impact of the pandemic can be a factor driving a process of falling behind, in 2021, after the vaccines become available, the scope and speed of vaccination may be a defining factor of relative movements of GDP per capita.

The tragedy of Covid-19 and the challenges raised to face this pandemic nevertheless create important opportunities for reorientation of the direction of technological progress in general, and especially for countries under the traps evaluated in those two Special Issues. Such reorientation is especially urgent, because the sooner and the broader the vaccination process is completed, the sooner an economy can overcome the limitations of social distancing and other protective measures.

The speed and the scope of vaccination are sharply related to manufacturing, commercial and health resources. Developed countries have a better position in all those dimensions, and therefore they may be sanitarily safer faster than countries at the periphery. A recent world map of vaccinations Bloomberg (2021) shows, in general terms, a distribution that follows the old center-periphery divide.

Since there is a demand for billions of vaccines, and the supply of those vaccines is far from covering the population for collective immunity, this mismatch puts forward new problems for all countries, especially those at the periphery: how much manufacturing capacity for strategic assets such as vaccines (and other important medicines and devices) should a country build? Thinking globally, the provision of vaccines could be better organized if the world had a larger and more geographically decentralized distribution of resources for their production. ${ }^{13}$ This is a health-related manufacturing side of the formation of innovation systems at the periphery. In the papers presented in the two Special Issues, references to some capability in health-related sectors are mentioned: "basic pharmaceuticals" in Malaysia (Wong et al., 10), clusters in pharmaceutical and medical devices sectors in Mexico (Durán, 2019, pp., 98-100), the pharmaceutical industry in India (Joseph and Abrol, 2009), "islands of excellence" in health in South 13 A map of COVID-19 candidate vaccines and manufacturing capacity was prepared by Vaxmap (2021). 
Africa and so on. Such manufacturing experiences in health-related sectors might be starting points for further development, if the appropriate institutional architecture is put in place within a workable South - South cooperation framework

The Covid-19 pandemic has abruptly halted globalisation and raised critical questions about the superiority of shareholder capitalism, associated with financialization, globalisation and over-fragmented GVCs. Lee (2020) proposes a rebalancing between shareholder and stakeholder capitalism, so that emerging economies may restore their growth momentum in an inclusive way. The post-pandemic retreat of globalisation is a good opportunity to restore autonomy over interest rates and exchange rates in domestic economic policymaking, while imposing some adjustments over formerly excessive capital mobility.

The new economic and epidemiological global scenario suggests the need for a combination of, on the one hand, new policies to push investments in health-related industries and, on the other hand, processes to build health institutions that will enable reaching the whole population institutions that are key components of a welfare system. And in countries with high and intolerable levels of inequality, that are the source of vicious cycles that shape middle-income traps, the formation and consolidation of welfare systems help to overcome this structural blocking factor.

Therefore, a combined formation of innovation systems and welfare systems may be a reference for policies to overcome middle income traps, as there might be strong positive feedbacks between those two institutional arrangements.

Covid-19 is a contemporary challenge, but we must be prepared as new challenges and new pandemics are possible (Zimmer, 2020; Foreign Affairs, 2020). Present and future challenges suggest that substantial investments in health innovation systems may be unavoidable. As health innovation systems are at the intersection between innovation and welfare systems, those investments can be strong new focusing devices to reorient the direction of technological progress at the periphery - and probably, a strong engine to overcome the middle-income trap. 


\section{References}

ALBUQUERQUE, E. Brazil and the Middle Income Trap: its historical roots. Seoul Journal of Economics, v. 32, n. 1, pp. 23-62, 2019.

AMSDEN, A. The rise of "the rest": challenges to the West from late-industrializing economies. Oxford: Oxford University, 2001.

BANK FOR INTERNATIONAL SETTLEMENTS. $90^{\text {th }}$ Annual Report. Basel: BIS (disponível em www.bis.org), 2020.

BLOOMBERG. More Than 245 Million Shots Given: Covid-19 Tracker, 2021. Available at: https://www.bloomberg.com/graphics/covid-vaccine-tracker-global-distribution. Accessed: 01/03/2021.

CERQUEIRA, H; ALBUQUERQUE, E. M. China and the initial shock of the industrial revolution. Nova Economia, v. 30, n. especial, 2020.

CHANDLER JR., A. The Visible Hand - The Managerial Revolution in America Business. London: The Belknap Press of Harvard University Press, 1977.

CIMINI, F.; BRITTO, J.; RIBEIRO, L. C. Latin America: the long-term roots of a middleincome trap. Nova Economia, v. 30, n. especial, 2020.

DEUTSCHE WELLE. Coronavirus vaccine - how to distribute it around the world? 2020 (https://www.dw.com/en/coronavirus-vaccine-how-to-distribute-it-around-theworld/a-55746075).

DURÁN, C. Globalization and the scrambling process of catching up in Mexico. Seoul Journal of Economics, v. 32, n. 1, pp. 83-106, 2019.

FACE UFMG. Workshop on Development: Lock-ins, Traps and Catch Up - Parte 5" [Video], 2019. Youtube. Available at: https://youtu.be/ii7TMr7uJcM. Presentation starts at (2:03:00). Accessed: 01/03/2021.

FEITOSA, P. Creating your own path to move beyond the middle-income trap: lessons from Korea. Nova Economia, v. 30, n. especial, 2020.

FINE, B.; RUSTOMJEE, Z. The political economy of South Africa: from minerals-energy complex to industrialisation. London: Westview, 1996.

FOREIGN AFFAIRS. The next pandemic: why the world was not prepared for Covid-19? 2020. Available at: https://www.foreignaffairs.com/anthologies/2020-05-28/next-pandemic. Accessed: 01/03/2021.

FURTADO, C. Brasil: a construção interrompida. São Paulo: Paz e Terra, 1992.

GARCIA, R.; SUZIGAN, W.; SANTOS, U. Industrial upgrade, economic catch-up and industrial policy in Brazil: general trends and the case of mining. Nova Economia, v. 30, n. especial, 2020.

IMF. Republic of Korea, 2021. Avaliable at: https://www.imf.org/en/Countries/KOR. Acessed: 01/03/2021.

INATARAKUMNERD, P. Thailand's Middle-Income Trap: firms' technological upgrading and innovation and governance policies. Seoul Journal of Economics, v. 32, n. 1, pp. 107-135, 2019. 
IOL. SA scientists make important Covid-19 discovery, 2020. Available at: https://www.iol. co.za/news/south-africa/western-cape/sa-scientists-make-important-covid-19-discovery-46330621. Accessed: 01/03/2021.

JOSEPH, K. J.; ABROL, D. Science, technology and innovation policies in India: Achievements and limits. BRICS and development alternatives: Innovation systems and policies, 1, pp. 101-131, 2009.

JOSEPH, K.J. FACE UFMG. Workshop on Development: Lock-ins, Traps and Catch Up - Parte 3" [Video], 2019. Youtube. Available at: https://youtu.be/6m71KQc1Ehk. Presentation starts at (11:00). Accessed: 01/03/2021.

JOSEPH, K.J; KAKARLAPUDI, K. K; JOSEPH, A. Deindustrialization and innovation under globalization: An Analysis of India's catch up in manufacturing. Nova Economia, v. 30, n. especial, 2020.

KRUSS. Glenda. FACE UFMG. Workshop on Development: Lock-ins, Traps and Catch Up - Parte 2" [Video], 2019. Youtube. Available at: https://youtu.be/R64qjhM7Jgg. Presentation starts at (03:15). Accessed: 01/03/2021.

KRUSS, G. Catching up, falling behind: the need to build upgrading coalitions for innovation and inclusive development in South Africa. Nova Economia, v. 30, n. especial, 2020.

LEBDIOUI, AMIR, KEUN LEE, CARLO PIETROBELLI. 'Local-Foreign Technology Interface, Resource-based development, and Industrial policy: How Chile and Malaysia are escaping the Middle Income Trap,' Journal of Technology Transfer. DOI: 10.1007/s10961-02009808-3, 2020.

LEE, K. (2013) Schumpeterian analysis of economic catch up: knowledge, path-creation, and the middle-income trap. Cambridge: Cambridge University Press.

LEE, K. (Ed). Political Economy of the Middle Income Trap. Special Issue. Seoul Journal of Economics, v. 32, n. 1, 2019a. Available at: http://www.sje.ac.kr/_common/ do.php? $\mathrm{a}=$ full $\& \mathrm{~b}=3 \& \mathrm{bidx}=2257$.

LEE, Keun. FACE UFMG. Workshop on Development: Lock-ins, Traps and Catch Up - Parte 1" [Video], 2019b. Youtube. Available at: https://youtu.be/4qlHJ_qiO1U. Book lauch starts at 00:14. Accessed: 01/03/2021.

LEE, Keun. FACE UFMG. Workshop on Development: Lock-ins, Traps and Catch Up - Parte 1" [Video], 2019c. Youtube. Available at: https://youtu.be/4qlHJ_qiO1U. Presentation starts at (24:00). Accessed: 01/03/2021.

LEE, K. "Varieties of capitalism and rethinking the East Asian model of economic growth after the Covid-19 pandemic: Rebalancing shareholder and stakeholder capitalism," Seoul Journal of Economics Vol. 33, No. 4: 485-504, 2020.

LEE, K. China's Technological Leapfrogging and Economic Catch-up: A Schumpeterian Perspective. Oxford: Oxford University Press (forthcoming), 2021.

LEE, K., Szapiro, M., \& Mao, Z. "From global value chains (GVC) to innovation systems for local value chains and knowledge creation". The European Journal of Development Research, 30(3), 424-441, 2018.

MADDISON, A. Historical statistics of the World Economy-1-2008 AD. Groningen Growth and Development Centre, 2010 (disponível em http://www.ggdc.net/maddison/Histori- 
cal_Statistics/horizontal-file_02-2010.xls).

NAUGHTON, B. (2007) The Chinese economy: transitions and growth. Cambridge/London: The MIT Press, 2007.

NELSON, R. A theory of the low level equilibrium trap in underdeveloped economies. American Economic Review, v. 46, pp. 894-908. 1956.

NORMILE, D. Pandemic could mark 'turning point' for Chinese science. Science, 14 January 2021, doi:10.1126/science.abc3208. Available at: https://www.sciencemag.org/ news/2021/01/pandemic-could-mark-turning-point-chinese-science. Accessed on $10 / 03 / 2021$.

SUZIGAN, W.; VILLELA, A. V. Industrial policy in Brazil. Campinas: Universidade Estadual de Campinas Instituto de Economia, 1997.

SZELÉNYI, I. A theory of transitions. Modern China, v. 34, n. 1, pp. 165-175, 2008.

TOOZE, A. Crashed: how a decade of financial crises changed the world. New York: Viking., 2018.

VAXMAP. An open source-based map of COVID-19 candidate vaccines and manufacturing capacity, 2021. Available at: http://vaxmap.org/.

WHO. Draft landscape and tracker of COVID-19 candidate vaccines, 2021. Available at: https://www.who.int/publications/m/item/draft-landscape-of-covid-19-candidate-vaccines.

WONG, C.; FUNG, H. Caught -in or breaking-free from the Middle Income Trap: the case of Malaysia. Seoul Journal of Economics, v. 32, n. 1, pp. 1-22, 2019.

WORLD BANK. China 2030: Building a Modern, Harmonious, and Creative High-Income Society. Washington, D.C.: World Bank, 2012.

WORLD BANK. World Bank Open Data - GDP per capita, PPP, 2020a. Available at: https:// data.worldbank.org/indicator/NY.GDP.PCAP.PP.KD.

WORLD BANK (2020b) World Bank Open Data - Gini index (World Bank estimate), 2020b (https://data.worldbank.org/indicator/SI.POV.GINI).

WORLD BANK, Global economic prospects. Washington: The World Bank, 2021.

YASAR, M. Can Turkey escape from Middle Income Trap? What has been done? What can be done? Lessons from South Korea. Seoul Journal of Economics, v. 32, n. 1, pp. 63-82. 2019.

ZIMMER, C. Welcome to the virosphere. The New York Times, 24 March 2020. Available at: https://www.nytimes.com/2020/03/24/science/viruses-coranavirus-biology.html.

ZIMMER, C.; CORUM, J.; WEE, S. Coronavirus vaccine tracker. The New York Times, 20 January 2021. Available at: https://www.nytimes.com/interactive/2020/science/coronavirusvaccine-tracker.html.

\section{About the authors}

Glenda Kruss-gkruss@hsrc.ac.za

Human Sciences Research Council, Cape Town, South Africa.

ORCID: https://orcid.org/0000-0002-0946-785X. 


\section{KeunLee-kenneth@snu.ac.kr}

Seoul National University, Seoul, South Korea.

ORCID: https://orcid.org/0000-0002-0403-6348.

KJ Joseph-director@gift.res.in

Gulati Institute of Finance and Taxation, Thiruvananthapuram, India.

ORCID: https://orcid.org/0000-0003-0369-2674.

Eduardo da Motta e Albuquerque-albuquer@cedeplar.ufmg.br

Centro de Desenvolvimento e Planejamento Regional, Universidade Federal de Minas Gerais, Belo Horizonte, Brazil. ORCID: https://orcid.org/0000-0002-1591-875X. 